\title{
Methane Emission Measurements in Urban Areas in Eastern Germany
}

\author{
JOANNE H. SHORTER, J. BARRY MCMANUS and CHARLES E. KOLB \\ Aerodyne Research, Inc., Billerica, Mass., U.S.A.
}

EUGENE J. ALLWINE and BRIAN K. LAMB

Washington State University, Laboratory for Atmospheric Research, Pullman, Washington, U.S.A.

BYARD W. MOSHER and ROBERT C. HARRISS

Complex Systems, University of New Hampshire, Durham, New Hampshire, U.S.A.

UWE PARTCHATKA, HORST FISCHER, GEOFFREY W. HARRIS and

PAUL J. CRUTZEN

Max.Planck Institut fuir Chemie, Mainz, Germany

HANS-JOSEF KARBACH

Institut für Troposphärenforschung e.V., Leipzig, Germany

\begin{abstract}
We have investigated methane emissions from urban sources in the former East Germany using innovative measurement techniques including a mobile real-time methane instrument and tracer release experiments. Anthropogenic and biogenic sources were studied with the emphasis on methane emissions from gas system sources, including urban distribution facilities and a production plant. Methane fluxes from pressure regulating stations ranged from 0.006 to 24 . $1 / \mathrm{min}$. Emissions from diffuse sources in urban areas were also measured with concentration maps and whole city flux experiments. The area fluxes of the two towns studied were 0.37 and $1.9 \mu \mathrm{g} / \mathrm{m}^{2} / \mathrm{s}$. The emissions from individual gas system stations and total town emissions of this study are comparable to results of similar sites examined in the United States.
\end{abstract}

Key words: tropospheric methane, $\mathrm{CH}_{4}$ emissions, natural gas, tracers.

\section{Introduction}

The global community has begun to recognize that it is imperative to identify and monitor greenhouse gases, including methane, in both industrialized and developing countries. The Conference of Parties to the Rio Treaty on Climate Change held in Berlin in April 1995 highlighted the need to study changes in methane emissions. The conference also called for cuts in greenhouse gas emissions and to accomplish this, identified a basic need of improved monitoring of all greenhouse gas emissions, not just that of $\mathrm{CO}_{2}$. The meeting emphasized the many unknowns in the levels of $\mathrm{CH}_{4}$ emissions in various energy sectors, such as petroleum sources and 
natural gas systems, and also from other anthropogenic sources such as landfills, agricultural areas (e.g. rice paddies), and farm animals.

Methane $\left(\mathrm{CH}_{4}\right)$ is a very powerful greenhouse gas as well as a participant in reactions in both the troposphere and stratosphere. It has a global warming potential (GWP) that is over 20 times that of carbon dioxide $\left(\mathrm{CO}_{2}\right)$ on a molecule/molecule basis (IPCC, 1990; Lelieveld and Crutzen, 1992). Lelieveld and Crutzen estimate the climate forcing of methane for a 10 year time scale to be 24.9 times that of $\mathrm{CO}_{2}$ when indirect chemical effects are included. The measurement of methane levels in the atmosphere has shown a general increase of $\sim 1 \%$ per year since the start of the industrial age (Blake and Rowland, 1988). Such an increase in $\mathrm{CH}_{4}$ contributes not only to the greenhouse effect but can lead to other atmospheric perturbations. An increase in tropospheric methane brings about an increase in tropospheric ozone levels and a decrease in tropospheric $\mathrm{OH}$, the atmosphere's scrubber. In the stratosphere methane oxidation is an important source of water vapor and therefore $\mathrm{HO}_{x}$ radicals, which have both important direct and indirect roles in stratospheric ozone depletion.

Recently Dlugokencky et al. (1994) reported a sharp decrease in the growth rate of atmospheric methane, particularly in the Northem Hemisphere. Between 1983 and 1991 the average increase in $\mathrm{CH}_{4}$ was $11.6 \pm 0.2 \mathrm{ppbv} \mathrm{yr}^{-1}$ and $11.1 \pm 0.2$ $\mathrm{ppbv} \mathrm{yr}^{-1}$ for the Northern and Southern Hemispheres, respectively. But in 1992 the increase was only $1.8 \pm 1.6 \mathrm{ppbv}$ and $7.7 \pm 1.0 \mathrm{ppbv}$ for the northern and southern hemispheres, respectively. This observation by Dlugokencky et al., has generated much speculation and controversy about the identity of the source of the decrease, including lower levels of emissions from eastem European and Russian natural gas systems (Hogan and Harriss, 1994; Kerr, 1994; Dlugokencky et al., 1994; Rudolph, 1994; Bekki et al., 1994). The basic problem is that a good understanding of all of the sources and sinks of atmospheric methane and how they may have changed recently has yet to be formulated. Changes in anthropogenic and natural sources, including biomass burning, wetlands, the eruption of Mount Pinatubo in 1991, and fossil fuel exploration, particularly in the former Soviet Union and Eastern Europe, have all been suggested as possible contributors to the observed methane decrease.

A goal of the work reported here was to investigate methane emissions in eastern Europe. We have focussed on gas systems because the mitigation of emissions of natural gas is a potentially powerful means of decreasing the total anthropogenic emission of $\mathrm{CH}_{4}$. Natural gas is considered a 'clean' fossil fuel because when burned it releases less carbon dioxide per unit of energy obtained than do other fossil fuels. It also emits fewer particulates and sulfur oxides. However, natural gas is typically $\sim 90 \%$ methane and is a potent source of global methane. The issue of fuel switching, from coal and oil to natural gas, involves consideration of the extent of the decrease in $\mathrm{CO}_{2}$ and increase in $\mathrm{CH}_{4}$ released into the atmosphere when the switch is made. The amount of natural gas methane released to the atmosphere has been estimated to be between 25 and $50 \mathrm{Tg} / \mathrm{yr}$ by IPCC(1990) and up to $70 \pm 15$ $\mathrm{Tg} / \mathrm{yr}$ by Lelieveld and Crutzen (1992) when natural gas leakage at oil wells is 
included. On a 10 year time horizon, Lelieveld and Crutzen estimate that one requires the gas leakage to be less than 2.4 to $2.9 \%$ to attain a reduction in climate forcing by switching from oil to gas and less than 4.3 to $5.7 \%$ leakage for gas to be preferred over coal. For a 20 year time scale the breakeven points are $2.8-3.3 \%$ for oil to gas and $4.9-6.3 \%$ for coal to gas. The differences in the two time horizons are a reflection of the difference in the lifetimes of $\mathrm{CO}_{2}$ and $\mathrm{CH}_{4}$ molecules in the atmosphere. Because the gas systems in different countries throughout the world differ in many respects including construction and maintenance, the system leakage in each country or region needs to be considered individually when deciding if fuel switching would be beneficial.

There are limited data on global methane emissions, particularly those from gas systems. An extensive set of measurements of methane emissions in U.S. urban areas with emphasis on the natural gas systems was performed by a team of scientists from Aerodyne Research, Inc. (ARI), Washington State University (WSU) and the University of New Hampshire (UNH) (McManus et al., 1994; Lamb et al., 1995; Shorter et al., 1996). Methane fluxes from components in all sectors of the natural gas system were measured. Total methane fluxes from urban areas, including contributions from both natural gas system components and other sources, were also studied. The methane fluxes normalized to throughput for eight small cities in the U.S. ranged from approximately 1 to $14 \%$. Two major metropolitan areas also examined were found to have numerous sources of atmospheric methane emissions. In addition, Blake et al. (1984) collected 22 urban air samples from a number of different geographical locations over a four year period. These sites included several in Poland, West Germany, and Britain. They observed elevated methane levels in urban areas, yet they did not attempt to estimate the contribution of the natural gas systems to the total methane elevation. The leakage rate of the British gas system has been estimated at $<1 \%$ by British Gas but up to $11 \%$ by others (Wallis, 1990, 1991), reflecting the uncertainty in emission data. Hogan et al. (1991) estimated that oil and gas account for global emission of 25 to 45 $\mathrm{Tg} \mathrm{CH} \mathrm{CH}_{4}$ per year with most of the emissions probably occurring in developing countries, Eastern European countries and in the former Soviet Union. There have been suppositions about poor maintenance of the gas systems in these areas and the possibility of improvements in maintenance attributing to the slowing of the global $\mathrm{CH}_{4}$ increase. The measurements and estimates cited above indicate that urban areas are generally important sources of methane. Natural gas leakage may be an important contributor to elevated urban $\mathrm{CH}_{4}$ levels, yet definitive data are not available.

The study presented here focuses on emissions from gas distribution and transmission systems in eastern Germany. For the transmission system, only the stations where gas is directly supplied to the distribution system, at times also considered as part of the distribution system, were included in the study. Leakage from the remainder of the transmission system, including pipeline transmission and storage of natural gas, may be important sources of methane in eastern Europe. Extensive 
studies have found that leakage in the United States from natural gas transmission and storage sites make up the largest portion of the total system emissions. This is followed by the production and distribution segments with the same leakage within error, and finally the gas processing segment (Harrison and Cowgill, 1996). Emissions from the different sites in eastern Europe may be similarly distributed. Whether or not transmission sites in eastern Europe, for example, are leakier than those in the west is left to be determined by future measurement studies.

The overall goal of the work was the direct measurement of emissions from gas transmission and distribution, particularly in areas of the world for which there is little data. We report here the results of measurements made in the former East Germany in the spring of 1992. The emphasis of the measurements presented in this paper is on the emission of methane from gas system sources including urban distribution facilities and a production plant. In the distribution system we concentrated on the largest potential sources, the town pressure regulating stations. Diffuse sources in urban areas were also studied. Innovative techniques including a mobile real-time methane measuring instrument and tracer release experiments were employed.

\section{Measurement Sites}

Urban methane emissions were studied in three towns (Torgau, Wurzen, and Eilenburg) outside of Leipzig, Germany. The towns have populations between 19,000 and 22,000 and are each approximately $9 \mathrm{~km}^{2}$ in area. Of these towns only Torgau had a natural gas system in spring of 1992 . The others had town gas systems, but there is a program in place in Germany to convert town gas systems to natural gas. Wurzen switched to natural gas in the spring of 1993 while Eilenburg made the switch later in that year. In general the town gas network of pipes and stations are used for natural gas after they are tested for leakage. The three towns are representative of small cities in eastern Germany. Their choice for the study was based on their location near Leipzig and on criteria of town size, compactness, road network, a minimum of major industry, and the presence of a natural gas or town gas system. In addition to the three towns, methane emissions at a town gas production facility in Böhlen, a town south of Leipzig, as well as overall urban methane levels in the Leipzig area, were measured.

Town gas is manufactured at several sites in eastern Germany. Different processes are utilized including a chemical mixing process and 'roasting' brown coal. The gas is distributed at high pressure to the local town systems. Both Eilenburg and Wurzen obtained their gas from a factory in Böhlen. This site produces town gas through a chemical mixing process in which hydrogen gas, natural gas imported from Russia, and a low quality domestic gas are combined according to quality standards of its caloric worth. The town gas transmitted to the towns is dry and contains approximately $28 \% \mathrm{CH}_{4}, 38 \% \mathrm{H}_{2}$ and $30 \% \mathrm{~N}_{2}$. It is odorized at the production factory prior to transmission. The natural gas systems in eastern Germany obtain 
their gas from Russia. It contains $\sim 99 \% \mathrm{CH}_{4}$ and is odorized in the individual towns. All of the systems examined appeared well maintained.

Torgau is a small industrial town located on the Elbe River. It has had a natural gas system since 1973. There are two main high pressure regulating stations where the pressure is decreased from 15 bar to 5 bar. The gas is odorized at the stations. One of these sites also has regulators to decrease the pressure from 5 bar to 20 mbar. There are four additional pressure regulating stations in Torgau that reduce the pressure from 5 bar to 20 mbar for general distribution. In addition, one major gas user, a glass factory, has its own pressure regulating station.

Eilenburg, located on the Mulde River, has a town gas system. There is one high pressure and three low pressure regulating stations. The high pressure ('main') station has an intake pressure of 11 bar and output pressure of 1.1 bar. The three other stations reduce the pressure from 1 bar to $12 \mathrm{mbar}$ for distribution. One of the large industrial users in Eilenburg has its own small regulating station.

The main facilities of the town gas system in Wurzen consist of one high pressure station where the gas is decreased from 16 bar to 4 bar, and 4 pressure regulating stations where the pressure is further reduced to $12 \mathrm{mbar}$. One of the latter serves only six small users. There are three factories in the town that are principal consumers of the gas. Each is supplied with gas at 4 bar and has its own pressure regulating station.

\section{Experimental Section}

\subsection{EXPERIMENTAL METHODS}

Three measurement strategies deployed in the program are surveys/mapping of methane in urban areas, hot-spot flux measurement, and whole-town methane flux measurement. The measurements were primarily performed at night, when the air is more stable and methane plumes are much more apparent. Another advantage of nighttime measurements is that interferences from automobile exhaust emissions is greatly reduced. The experimental methods employed in the measurement of methane emissions have been described elsewhere in detail (Lamb et al., 1995). A brief description of each method follows.

Each urban area was surveyed with the mobile $\mathrm{CH}_{4}$ and $\mathrm{CO}_{2}$ instruments in order to determine their overall emission characteristics and to identify high methane emitters, or 'hot spots'. Methane emissions from selected 'hot spot' sources were later measured. Methane 'maps' of a city were generated from sampling traverses made throughout the city in a single night.

The methane concentration information gained from surveys is insufficient to determine methane emission rates. Emission measurements can be made at identifiable point sources using the tracer ratio method (Lamb et al., 1995; Lamb et al., 1986). The measurement technique is based on the quantified release of some easily detectable tracer gas (typically sulfur hexafluoride, $\mathrm{SF}_{6}$ ) co-located with the methane emission point. The concentrations of the two gases (i.e., $\Delta C_{m}$, 
methane elevation above local background, and $C_{t}$, tracer elevation) are measured downwind of the leak/release point. Although there are some industrial uses of $\mathrm{SF}_{6}$ which could potentially introduce a non-zero background of $\mathrm{SF}_{6}$, background levels of the tracer is typically effectively zero. The methane leakage rate $\left(Q_{m}\right)$ is determined from the ratio of concentrations, and the known tracer release rate $\left(Q_{t}\right)$, i.e. $Q_{m}=Q_{t} \Delta C_{m} / C_{t}$. This type of measurement is valid if the tracer release accurately simulates the methane source.

In tracer ratio experiments the downwind air is sampled both with stationary canister samplers and with mobile real-time instruments. Between 4 and 8 portable canister samplers are used in each test. The real-time instruments are extremely valuable in locating the plume, to facilitate placement of the canister samplers within the plume. At the sites studied here, the methane emissions were often quite small. It was thus crucial to accurately locate the canisters to maximize the overlap of the canisters with the plumes.

Fluxes are also determined from the mobile instrument data. The mobile measurements typically are conducted by locating the downwind plumes, then either repeatedly driving back and forth through the plumes or by collecting stationary measurements while parked downwind of the source. The emission rates are based on the ratio of the integrals of the tracer and methane concentrations above background.

A variation of the tracer method was applied to a small enclosed regulating station in Eilenburg. A known amount of tracer was injected into the enclosure and allowed to mix with the air in the enclosed space. Several canister air samples were collected and later analyzed for $\mathrm{CH}_{4}$ and $\mathrm{SF}_{6}$. The methane flux of the station was calculated from the methane levels and the ventilation rate, determined from the change in $\mathrm{SF}_{6}$ concentration over time.

City methane fluxes are measured using the 'modified tracer ratio method'. This technique is based on tracer releases from near the urban center and concentration measurements along a cross- wind traverse at the downwind edge of the town or large area source. The modified tracer approach relies on both tracer concentration data and an atmospheric model to determine the atmospheric mixing behavior. All of the needed input quantities are directly measurable. The vertical diffusion can be obtained from the measurement of the tracer plume via mass balance, or it can be taken from diffusion data in the literature, given information about the stability conditions. It is then employed in a Gaussian plume model. The method contains the assumption that the city can be approximated as a uniform area source and that the boundaries of the emissions can be determined. The distances from the upwind and downwind edges of the area source to the measured plumes are used in the analysis. The emission boundaries were determined by methane surveys and by maps that indicated density of housing. The method combines the plume model with the average downwind elevation in methane to derive the area emission rate. Details of the measurement method and analysis is given in Lamb et al. (1995). 
City flux measurements typically were conducted with the $\mathrm{SF}_{6}$ release located one third of the distance from the upwind to downwind sides of the city, and near the center in the crosswind direction. City tests were conducted under stable conditions at night, with wind speeds generally less than $2 \mathrm{~m} / \mathrm{s}$. Due to both the relatively weak plumes that we observed and the variability of the background methane levels, measurement traverses generally were not conducted more than a fraction of a city diameter downwind of the city.

The background methane levels were determined from the ends of the crosswind traverses. This yields high sensitivity to city plume elevations in concentration and allows multiple background determinations to be made during the course of a test, which are important for high accuracy measurements. Accumulating methane or shifting winds can cause the background to change during a test lasting several hours.

The whole town method can also be applied to other large area sources, as we did at the production facility in Böhlen. We report here the application of this method to obtain whole town methane emissions of Torgau and Eilenburg and the total site emission from the town gas production site.

\subsection{INSTRUMENTATION}

Field measurements were conducted with instruments carried in two vehicles. The measurements vehicle carried a suite of real time instruments capable of operation at normal road speeds: an ARI methane monitor, WSU $\mathrm{SF}_{6}$ analyzer, $\mathrm{CO}_{2}$ analyzer, a Global Positioning System (GPS) receiver, and a linear distance measurement device. The sampling height of the mobile measurement van was 2 $\mathrm{m}$. The release van held the $\mathrm{SF}_{6}$ tracer release system. The real time instruments have been described in detail previously (Lamb et al., 1995; McManus et al., 1989, 1990, 1993). A brief description will be given here.

The mobile methane monitor is a unique, high accuracy real-time monitor. A similar instrument has been used extensively for measurements in the United States (McManus et al., 1991a; Fan et al., 1991; McManus et al., 1989; Czepiel et al., 1996). The methane instrument is based on the absorption of infrared laser radiation. A precisely controlled infrared $\mathrm{HeNe}$ laser is rapidly tuned on and off an absorption line of methane near 3.39 microns wavelength $\left(2947.91 \mathrm{~cm}^{-1}\right)$. Absorption within a multipass optical cell containing the sampled air stream is measured. The instrument is sensitive to changes in ambient concentration of about $0.3 \%$ of the ambient level, or 5 parts-per-billion-by volume (ppbv) methane (rms noise levels at $1 \mathrm{sec}$. averaging). The response time of approximately 6 seconds is due to the gas flow time through the sampling cell.

The sulfur hexafluoride instrument, a continuous tracer analyzer that is based on a custom built electron capture detector by Simmonds et al. (1976), was developed at WSU as a fast response instrument for routine field operation (Benner and Lamb, 1985). The instrument has a response time of $0.4 \mathrm{~s}$ and a detection limit of less than 
10 parts-per- trillion-by volume (pptv). The instrument is calibrated periodically during each sampling period using $\mathrm{SF}_{6} /$ air standards over the range $25 \mathrm{pptv}$ to 3.5 ppbv ( $\pm 5 \%$ certified accuracy, Scott-Marrin, Inc.).

A carbon dioxide analyzer (LiCor LI-6262) was included in the suite of mobile instruments as a means of identifying combustion sources. The instrument measures $\mathrm{CO}_{2}$ concentrations to within 1 part-per-million-by volume (ppmv) with an averaging time of $1 \mathrm{~s}$.

Whole air samples for measurement of methane, light hydrocarbons, and $\mathrm{SF}_{6}$ were collected in electropolished stainless steel canisters using portable samplers developed at WSU. During a 30 minute sampling period, the evacuated canisters were pressurized to approximately $20 \mathrm{psig}$ at a steady rate. Approximately 4 to 8 samples were collected using the portable samplers during a tracer flux test. The samples were later analyzed at WSU.

The canister samples were analyzed for methane using flame ionization gas chromatography with a fixed gas sampling loop. The instrument was calibrated with a commercial standard traceable to NIST standards. Each air sample was analyzed at least four times to obtain precision levels of approximately $10 \mathrm{ppb}$ or less. Air samples were analyzed for sulfur hexafluoride using an electron capture gas chromatograph (HP 5880) calibrated periodically with commercial standards. The precision levels of the tracer analyses were typically less than $5 \%$.

The $\mathrm{SF}_{6}$ tracer was released from gas cylinders through a regulator to the automated mass flowmeter. Periodic measurements with a calibrated dry gas meter were also made to confirm the flow rates.

The GPS provides location information in three dimensions at a data rate of approximately 1 measurement per second. A two receiver system, including a mobile receiver in the measurement van and a stationary receiver at a reference location, allows a relative position accuracy of the mobile unit of 5 meters to be achieved. A linear distance measurement device was also mounted in the van to obtain linear distance versus time data.

The towns in Germany presented a number of experimental challenges. The mobility of the measurement vehicle was limited in areas of the towns. For example, the road surface quality was poor in sections. There are many cobblestone streets and a number of truck or vehicle exclusion zones in town centers. These conditions preempted urban screening in these areas. The abundance of connected buildings also led to channeling of air and complicated air flow patterns. Particular attention to the measurement conditions were necessary during urban screening measurements and emission tests at stations located in such areas.

\section{Results}

\subsection{URBAN AREA SCREENING}

Methane concentration data from traverses throughout a town are combined with positioning data to generate three dimensional maps of methane level as a function 


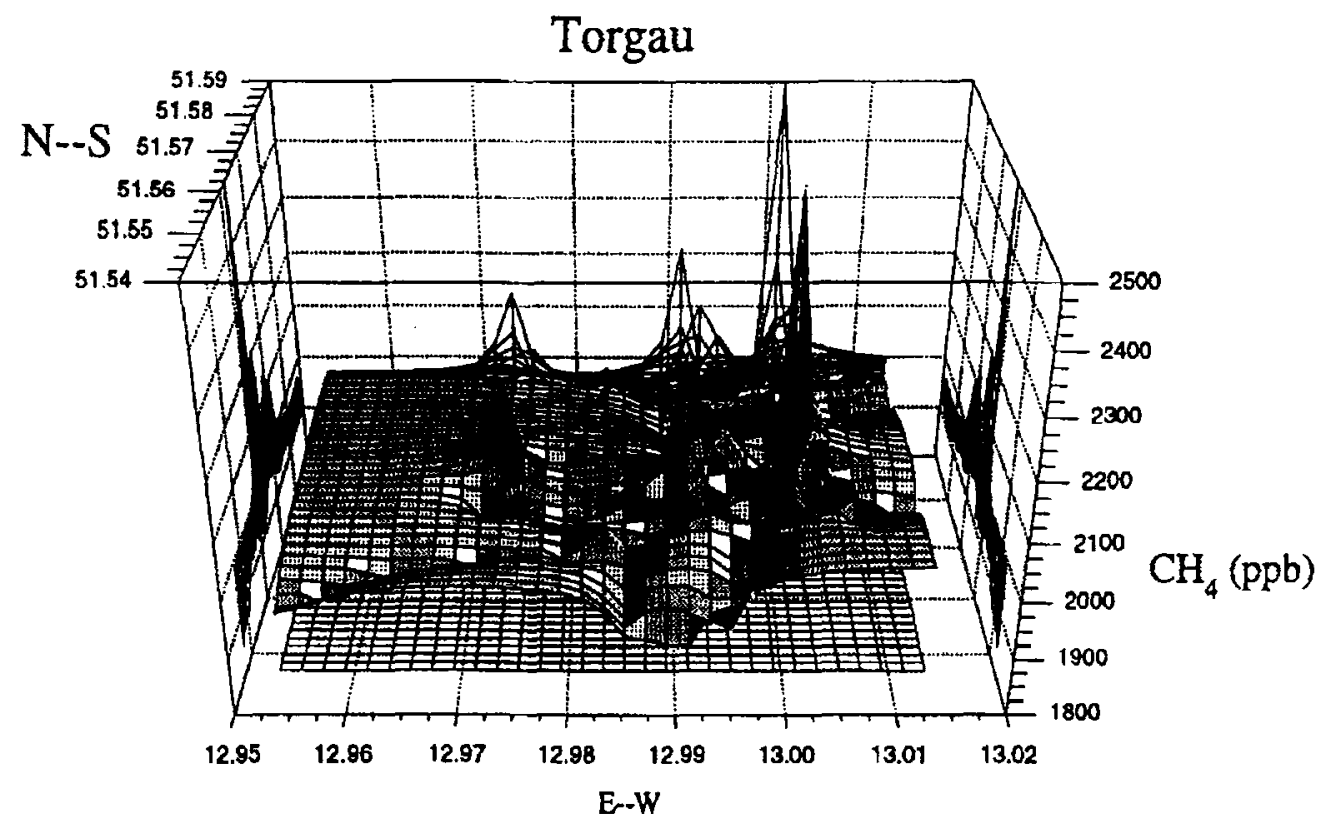

Figure 1. Methane concentration map of Torgau as a function of location. Cross section plots of $\mathrm{CH}_{4}$ are shown on the side panels. The $x$ and $y$ axes are in units of degrees longitude and latitude, respectively.

of location (latitude and longitude). These 'maps' give an overall picture of all of the methane sources in the town as well as the general $\mathrm{CH}_{4}$ level for the area during the measurement period. It is important to note the weather conditions during a data collection effort since they can greatly affect atmospheric mixing and consequently the methane levels present. The data for the methane map of Torgau (Figure 1) were collected on 10-11 May 1992 under partly cloudy skies with southwest winds at $\sim 1.5 \mathrm{~m} / \mathrm{s}$. Small hotspots were measured in the town with one very large elevation detected in the town square (northeast side of the city). The background $\mathrm{CH}_{4}$ level was $\sim 1990 \mathrm{ppb}$.

The mapping experiment in Wurzen was conducted under very light winds, principally from the east. Small elevations in $\mathrm{CH}_{4}$ were measured throughout the city but no significant hotspots were detected. Methane levels ranged between about 1800 and $2600 \mathrm{ppb}$ throughout Wurzen, with levels generally higher on the west side of the city. This is consistent with the wind direction. Figure 2 is a smoothed surface plot of the methane data.

Traverses between urban centers can provide information about rural atmospheric $\mathrm{CH}_{4}$ concentrations. The characteristic plume of a city can also be identified on traverses made on the downwind edge of the city. The top panel of Figure 3 shows the methane levels on a route from Böhlen, a small town south of Leipzig, around the west side of Leipzig and to the east. Winds were from the north/northeast at $\sim 2 \mathrm{~m} / \mathrm{s}$. The methane levels south of Leipzig were generally around $1990 \mathrm{ppb}$ with several significant peaks also measured. Brown coal mines are located in the region of high methane and may have been the source of the elevation. A plot of the $\mathrm{CO}_{2}$ 


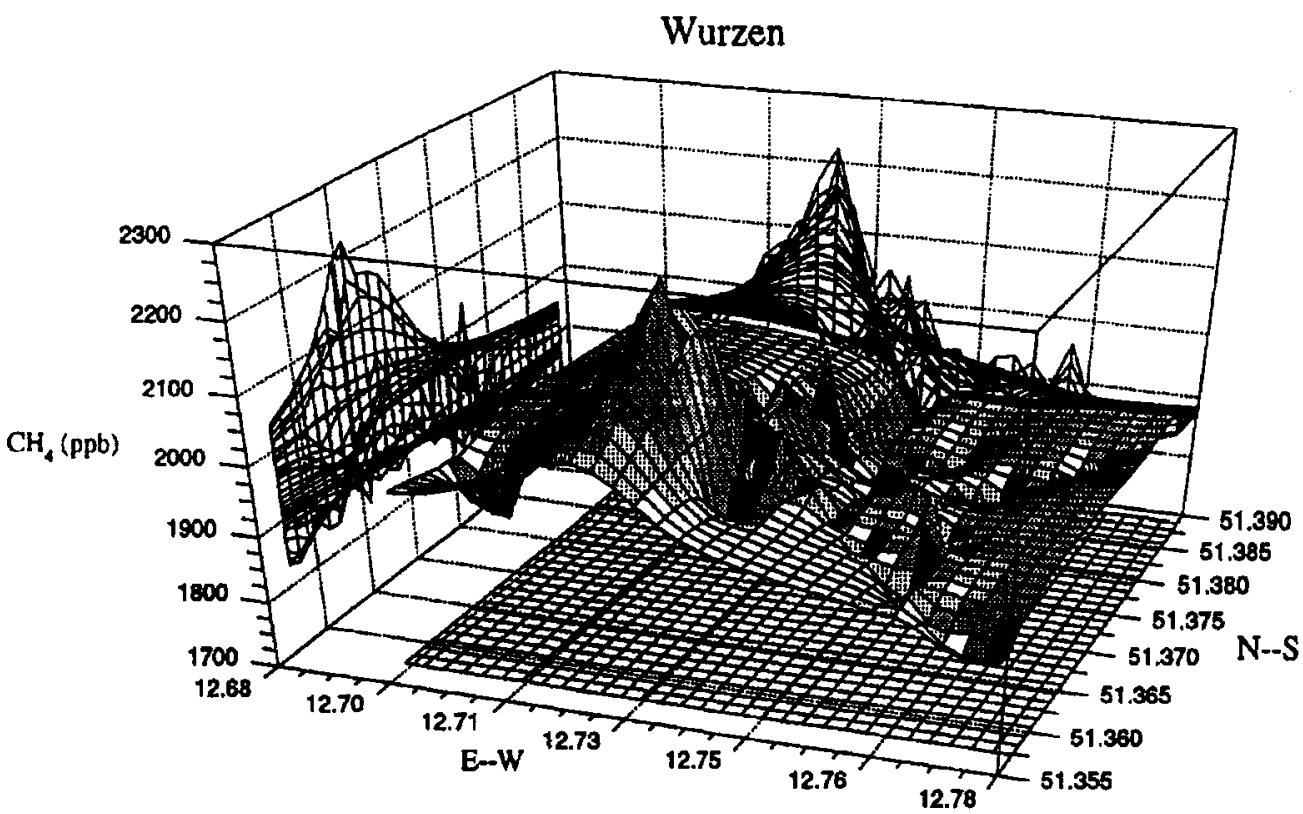

Figure 2. Methane concentration map of Wurzen as a function of location. Cross section plots of $\mathrm{CH}_{4}$ are shown on the side panels. The $x$ and $y$ axes are in units of degrees longitude and latitude, respectively.

levels along the traverse is shown in the bottom panel of Figure 3. Carbon dioxide levels ranged from 360 to $385 \mathrm{ppm}$ with several higher peaks. The sources of the $\mathrm{CO}_{2}$ elevations are not known. It is doubtful that automobiles were a significant source because there was very little traffic when the data were collected at about $0130 \mathrm{hr}$. General downwind elevations of both $\mathrm{CO}_{2}$ and $\mathrm{CH}_{4}$ from Leipzig were observed.

\subsection{DISTRIBUTION SYSTEM}

Point source $\mathrm{CH}_{4}$ flux measurements were conducted at pressure regulating stations in Torgau and Eilenburg. Both canister and real time instrument data were used to compare $\mathrm{CH}_{4}$ and $\mathrm{SF}_{6}$ elevations and obtain the methane fluxes from the sources. The results are given in Table I with the stations separated into pressure ranges and indicated as serving town or natural gas. The type of gas system of each site is important since the methane content of the town gas is significantly lower than in natural gas. Emissions from individual sites ranged from 0.0061 to 24.1 $1 / \mathrm{min}$. Large uncertainties are associated with some of the results of the tests at the pressure regulating stations. They are predominately attributed to small elevations of methane above background that were observed at the sites. The one very low emission rate was measured at a very small station in Eilenburg using an enclosure technique.

In Table II, methane emissions from the pressure regulating stations measured in Germany are combined and then compared to regulator stations studied in the 

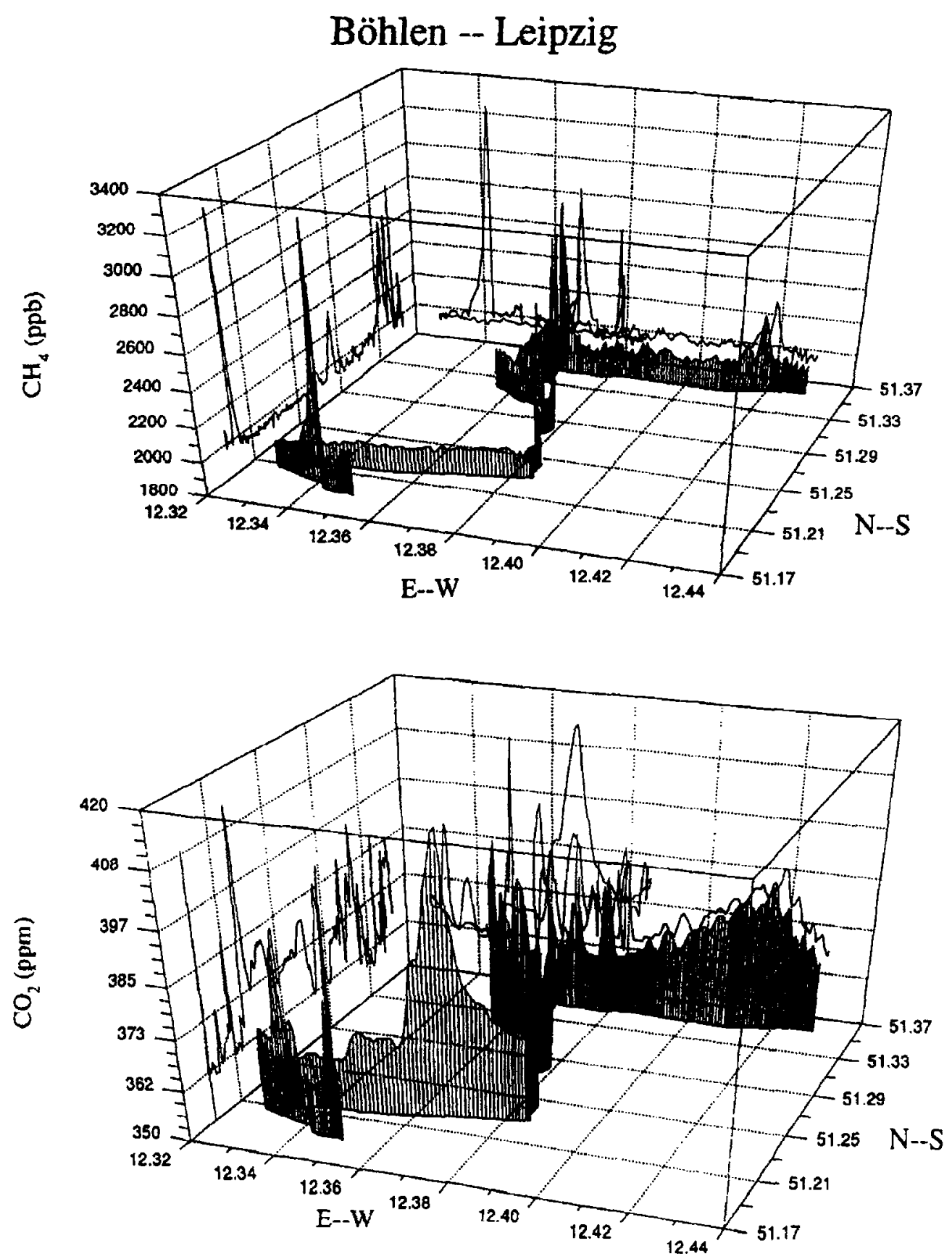

Figure 3. Methane concentration as a function of location for a traverse from Böhlen to and around the west and north side of Leipzig (a). $\mathrm{CO}_{2}$ versus location for the same traverse is given in the bottom panel (b). The $x$ and $y$ axes are in units of degrees longitude and latitude, respectively.

U.S. in an EPA/GRI sponsored program (McManus et al., 1993; Shorter et al., 1996). The methane fluxes in both the high and low pressure categories have a large range. 
Table I. Emission rates from pressure regulating stations and production site

\begin{tabular}{|c|c|c|c|c|}
\hline System & Site & $\begin{array}{l}\text { Emission rate }^{a} \\
1 / \mathrm{min}\end{array}$ & $\begin{array}{l}\text { Can/mobile } \\
\text { diff }^{\circ} \%\end{array}$ & $\begin{array}{l}\text { Leakage, } \\
\% \mathrm{CH}_{4} \\
\text { usage }\end{array}$ \\
\hline \multicolumn{5}{|c|}{ High pressure sites } \\
\hline Natural gas & Torgau-S main station & 2.08 & -66 & 0.0050 \\
\hline Natural gas & Torgau-NW main station & 24.1 & 32 & 0.057 \\
\hline Town gas & Eilenburg-Main station (I) & 3.86 & -89 & 0.070 \\
\hline \multicolumn{5}{|c|}{ Low pressure sites } \\
\hline Town gas & Eilenburg-Station II & 2.44 & 26 & \\
\hline Town gas & Eilenburg-Station III & 15.8 & 17 & \\
\hline Town gas & Eilenburg-Station IV & 0.00609 & & \\
\hline \multicolumn{5}{|c|}{ Production site } \\
\hline $\begin{array}{l}\text { Town gas/ } \\
\text { natural gas }\end{array}$ & Böhlen facility & 5230 & 40 & \\
\hline
\end{tabular}

${ }^{a}$ Average of rates from canister and mobile methods when both methods were used.

${ }^{\mathrm{b}} \mathrm{Can} / \mathrm{mobile}$ diff $=[\mathrm{rate}(\mathrm{can})-\mathrm{rate}($ mobile $)] /$ rate(average $) \times 100 \%$

Table II. Comparison of methane emission rates for U.S. and Germany regulating stations

\begin{tabular}{lll}
\hline Pressure class & $\begin{array}{l}\text { U.S. Regulator stations } \\
\text { V/min }\end{array}$ & $\begin{array}{l}\text { Germany Regulator stations } \\
\text { / } \mathrm{min}\end{array}$ \\
\hline $100-300 \mathrm{psi}$ & $19 \pm 17$ & $10.0 \pm 12.2$ \\
$40-100 \mathrm{psi}$ & $0.50 \pm 0.50$ & $6.08 \pm 8.50$ \\
\hline
\end{tabular}

The high pressure stations measured in Germany had a lower average methane emission rate than corresponding sites studied in the U.S. program, although the results are within the range of uncertainty. In contrast, the low pressure regulating stations sampled in Germany had higher methane emissions than those studied in the United States. The three measured German emission rates range from 0.00609 to $15.8 \mathrm{l} / \mathrm{min}$. The average rate of the measured U.S. low pressure stations, $0.50 \pm 0.50$ 1/min, represents a larger sampling set. All three German stations in the 40-100 psi class were measured in Eilenburg. When the Torgau stations in this class were surveyed no clear, consistent methane plumes were detected. Thus, the emissions appeared to be low, but no flux measurements were made to substantiate this.

As mentioned previously, the Eilenburg gas system is a town gas system. Given that $\sim 28 \%$ of town gas is methane, we can estimate the methane emission rates of the Eilenburg stations for a system with natural gas (assuming $100 \% \mathbf{C H}_{4}$ ). The main station (100-300 psi class) has an adjusted emission rate of $13.7 \mathrm{l} / \mathrm{min}$ which is only slightly lower than the average U.S. rate. The adjusted rates of the secondary stations $(8.7,56.4$, and $0.0218 \mathrm{l} / \mathrm{min}$ for stations II, III, and IV, respectively) have 
a larger deviation from the emission rates of corresponding U.S. stations than did the unadjusted rates.

It is possible to estimate the percentage of the gas that passes through a particular system component which leaks to the atmosphere. The total gas usages in Torgau and Eilenburg in May 1992 were $8.39 \times 10^{4} \mathrm{l} / \mathrm{min}$ and $1.97 \times 10^{4} \mathrm{l} / \mathrm{min}$, respectively (Gasversorgung Leipzig GmbH, private communication). In Eilenburg this corresponds to the throughput of the one main station and we can assume that the gas was distributed equally between the two high pressure stations in Torgau. The leakage of each station as a percentage of throughput is as given in Table I. In order to obtain the methane throughput for the Eilenburg station, the total gas throughput was multiplied by $28 \%$, the fraction of $\mathrm{CH}_{4}$ in town gas. The methane leakage percentages range from 0.0050 to $0.070 \%$.

\subsection{CITY TESTS}

Urban area emission measurements were conducted in Torgau and Eilenburg. A city test yields a methane flux which is the sum of all anthropogenic and biogenic $\mathrm{CH}_{4}$ sources in the town, i.e., both gas system and nongas system sources. As described above, a city test involves the release of a tracer gas from the upwind side of the town. Both the methane plume from the city sources and the tracer plume originating at the release are measured downwind of the city. The weather conditions during the experiment, including cloud cover and wind direction and speed, are used to describe the stability conditions in the application of the modified tracer technique.

The city test in Torgau was conducted on 12 May 1992. The wind was stable from the southwest at $1.5-3.2 \mathrm{~m} / \mathrm{s}$. The tracer was released from a parking lot on the west side of Torgau. Roughly North-South measurement traverses were made east of the city. The Elbe River was upwind of the traverses, but did not appear to affect the methane levels detected. Several plots of the real time $\mathrm{CH}_{4}$ and $\mathrm{SF}_{6}$ data are shown in Figure 4. There was only a small $\mathrm{CH}_{4}$ elevation from the city $(\sim 20-30$ ppb above background). The plume extended to the north as far as the next town. The traverses were not continued further to the north because of potential local $\mathrm{CH}_{4}$ sources. The $\mathrm{SF}_{6}$ plumes were fairly consistent in both elevation and location from one traverse to the next. Applying the modified tracer method to the data, a total $\mathrm{CH}_{4}$ flux of $1440 \mathrm{~V} / \mathrm{min}$ is estimated.

The Eilenburg city test was performed on 15-16 May 1992 under clear skies. The wind was from the east, initially $<1 \mathrm{~m} / \mathrm{s}$ and increasing to $\sim 1.5 \mathrm{~m} / \mathrm{s}$. The city has two main regions which are separated by the Mulde River which runs in the north-south direction. The $\mathrm{SF}_{6}$ tracer was released on the west side of the river, near the geographical center of the town. Measurement traverses were made on the west side of the town. The traverses were not made completely outside the emission boundary of the city because of limitations of the road system. There were no appropriate sampling roads within several kilometers of Eilenburg. North- 

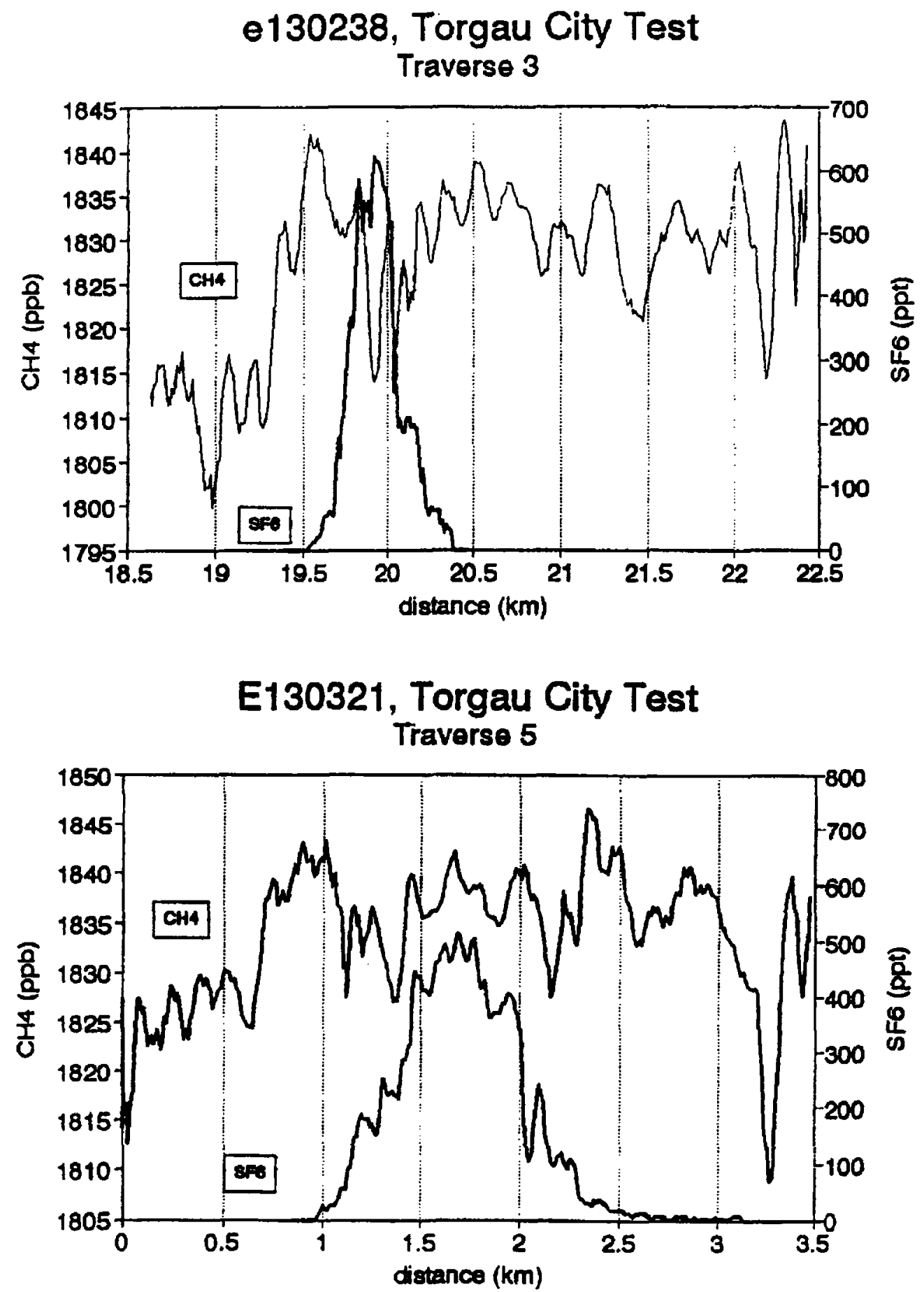

Figure 4. $\mathrm{CH}_{4}$ and $\mathrm{SF}_{6}$ concentrations versus distance travelled for two traverses of the Torgau city test on 12 May 1992.

south traverses were therefore made as close to the western boundary of the city as was possible. The average $\mathrm{CH}_{4}$ elevation in the city plumes on the traverses was approximately $70 \mathrm{ppb}$. Elevations in $\mathrm{CH}_{4}$ and $\mathrm{CO}_{2}$ from local point sources were seen on the south end of the traverses. They were due to a small water and sewage 
Table III. Total town methane emissions

\begin{tabular}{lllll}
\hline Town & Population & $\begin{array}{l}\text { Whole city test } \\
\text { emission } \\
(/ / \mathrm{min})\end{array}$ & $\begin{array}{l}\text { Total of gas system } \\
\text { measurements } \\
(\mathrm{V} / \mathrm{min})\end{array}$ & $\begin{array}{l}\text { Area flux } \\
\left(\mu \mathrm{g} / \mathrm{m}^{2} / \mathrm{s}\right)\end{array}$ \\
\hline Torgau & $\sim 21,380$ & 1440 & 26.2 & 1.90 \\
Eilenburg & $\sim 21,680$ & 260 & 22.1 & 0.371 \\
\hline
\end{tabular}

treatment plant located east of that region and are not included in the city plume for the flux calculation. The estimated (partial) city emission from the modified tracer technique analysis is $260 \mathrm{l} / \mathrm{min}$. We consider this a partial city emission because the city plume in the test did not include the main pressure regulating station $(Q=3.9$ $\mathrm{l} / \mathrm{min}$ ). The station was located downwind of the traverses, as necessitated by the layout of the road system.

City emissions estimated for Torgau and Eilenburg were 1440 and $2601 / \mathrm{min}$, respectively. The measurements are believed to be accurate to within $\pm 50 \%$. For a detailed description of the error estimate for the method see Lamb et al. (1995). The conditions present during both the Torgau and Eilenburg city tests are within the range of the conditions considered in the analysis. This estimate is therefore applicable to the results of the city tests studied here.

The total gas system emission may be estimated by either the modified tracer technique or from the total of the emissions from individually measured gas system sites. The latter technique, however, omits both stations which were not measured and diffuse emissions (underground leaks, leaks at customer meters, etc). An extensive measurement program in the U.S. concluded that in the U.S. gas system, underground leaks are significant contributors to the total emissions, but that customer meters are a relatively small source of methane emissions (Harrison and Cowgill, 1996). In Table III the estimates from the whole city test and the summation of measurements are compared for Torgau and Eilenburg. In each case the methane emission measured by the whole city test method is significantly higher than the sum of measured sources. The sum of measured emissions in Torgau includes only the two main regulating stations. It does not include other gas system sources: the four low pressure stations, the large regulating station at the glass factory, or a large leak repeatedly detected near the town square and assumed to originate from the gas system. Emissions from biogenic sources, such as wetlands along a stream in the central section of Torgau, and other anthropogenic sources including the sewer system, are encompassed by the city tracer technique.

The total of gas system measurements in Eilenburg includes all of the regulating stations with the exception of a small middle system station located at a factory. Yet the resulting total emissions from the stations is a factor of 10 lower than that calculated with the whole city method. It should be noted again that the modified tracer test in Eilenburg did not include the main pressure regulating station, which 
was located downwind of the traverses. When the measured emission rate of the main station is added to the city test result, the discrepancy between the results of the two methods is increased. A significant nongas system source of methane in Eilenburg is suspected to be the sewer system. On several occasions high methane and carbon dioxide levels were measured at sewer manhole covers in the town. There are also two water/sewage treatment plants in the town. The industrial sewage treatment plant located in the east side of the city may have contributed to the total measured methane flux.

The gas usage by the towns of Torgau and Eilenburg in 1992 can be used to estimate the maximum fraction of the total gas usage by each town which leaks to the atmosphere (Gasversorgung Leipzig $\mathrm{GmbH}$, private communication). During May 1992, the gas usage in Torgau was $121 \times 10^{3} \mathrm{~m}^{3} /$ day or $8.39 \times 10^{4} 1 / \mathrm{min}$. According to the city test results, $1440 \mathrm{l} / \mathrm{min}$ of methane was emitted from Torgau. Assuming that all of the methane came from the gas system, $1.7 \%$ of the throughput was emitted. The town gas usage in Eilenburg in May 1992 was $28.4 \times 10^{3} \mathrm{~m}^{3} / \mathrm{day}$, or $1.97 \times 10^{4} \mathrm{l} / \mathrm{min}$. This corresponds to a usage of $5.52 \times 10^{3} \mathrm{I} / \mathrm{min} \mathrm{CH}_{4}$. According to the modified tracer city test in Eilenburg, $260 \mathrm{l} / \mathrm{min}$ methane was emitted by the town. A maximum of $4.7 \%$ of the methane throughput in the gas system was emitted, assuming that the sole source of $\mathrm{CH}_{4}$ in the town plume was the gas system. If the sum of the tests at the individual stations in a town, instead of the city test results, are compared to the throughputs, we obtain the following. In Torgau the total $\mathrm{CH}_{4}$ leaking from the two stations studied, $26.2 \mathrm{l} / \mathrm{min}$, is equal to $0.031 \%$ of the gas throughput. The sum of the emission from the Eilenburg station, 22.1 $\mathrm{l} / \mathrm{min}$, is equal to $0.40 \%$ of the total $\mathrm{CH}_{4}$ usage for the town.

The city emissions of Torgau and Eilenburg can be compared to emissions measured in eight towns in the United States with populations ranging from 11,000 to 38,000 (Table IV) (McManus et al., 1993; Lamb et al., 1995). These towns were chosen for our U.S. measurement study because of their size, geographical compactness, and their lack of major industry. The total methane emission rate measured in these U.S. towns using the modified tracer technique ranged from 695 to $8490 \mathrm{~V} / \mathrm{min}$. The average emission rate of the U.S. towns is higher than the total emission from either German city, although the Torgau emission rate falls within the range of values. If one assumes that all of the methane emissions measured in Eilenburg originated from the gas system, then if the system contained natural gas $\left(99 \% \mathrm{CH}_{4}\right)$ rather than town gas $\left(28 \% \mathrm{CH}_{4}\right)$, the methane emission rate would be $920 \mathrm{l} / \mathrm{min}$. This would also fall within the range of emissions from the U.S. cities.

The average maximum percentage of the throughput emitted by the U.S. towns, based on the city tests, range from 0.9 to $14 \%$ (Table IV). If instead, the sum of the emissions from the gas system components is compared to the throughput, on average $0.3 \%$ of the throughput gas is emitted with the values ranging from 0.04 to $0.8 \%$ (three additional U.S. towns are included in this calculation). Using either method, the maximum percentage of throughput leaking from the Torgau system falls at the low end of the range. The maximum methane leakage from 
Table IV. Intercomparison of measured U.S. and German whole city emissions

\begin{tabular}{lcccl}
\hline City & Population & $\begin{array}{l}\text { Whole city } \\
\text { emissions } \\
\text { 1/min }\end{array}$ & $\begin{array}{l}\text { Whole city } \\
\text { emissions } \\
\text { normalized to } \\
\text { throughput, \% }\end{array}$ & $\begin{array}{l}\text { Area flux } \\
\mu \mathrm{g} / \mathrm{m}^{2} / \mathrm{s}\end{array}$ \\
\hline Torgau & 21,380 & 1440 & 1.7 & 1.90 \\
Eilenburg & 21,680 & 260 & 4.7 & 0.371 \\
U.S. Towns & & & & \\
MW \#2 & 15,300 & 1050 & 1.2 & 0.9 \\
MW \#4 & 35,000 & 3800 & 2.5 & 1.8 \\
SP \#1 & 37,700 & 4400 & 1.6 & 2.0 \\
SP \#2 & 36,700 & 1320 & 0.9 & 0.8 \\
TX \#1 & 11,000 & 3090 & 14 & 1.8 \\
TX \#3 & 23,000 & 695 & 1.2 & 0.3 \\
SE \#1 & 20,300 & 2290 & 2.4 & 1.2 \\
SE \#2 & 12,500 & 8490 & 13 & 5.9 \\
\hline
\end{tabular}

The modified tracer measurement results are believed to be accurate to within $\pm 50 \%$.

the Eilenburg town gas system based on the city test (4.7\%) is comparable to the average maximum leakage of the U.S. towns calculated by the city test method, while the leakage based on the summation method is slightly higher.

Area methane fluxes of the German and U.S. towns studied can also be compared. The area methane fluxes of Torgau and Eilenburg, determined from the emission rate and the area of each town, were $1.90 \mu \mathrm{g} / \mathrm{m}^{2} / \mathrm{s}$ and $0.371 \mu \mathrm{g} / \mathrm{m}^{2} / \mathrm{s}$, respectively. If we assume natural gas replacement in Eilenburg, the area flux based on the above measurement would be $1.32 \mu \mathrm{g} / \mathrm{m}^{2} / \mathrm{s}$. The average area flux of the eight U.S. towns studied with the modified tracer test was $1.8 \pm 1.7 \mu \mathrm{g} / \mathrm{m}^{2} / \mathrm{s}$ (Lamb et al., 1995). The area flux of each of the German towns, assuming natural gas use, is therefore comparable to the average U.S. flux.

These are very limited sets of data and the above discussion is only an attempt to give a relative 'benchmark' for the results of our experiments in the German towns.

\subsection{TOWN GAS PRODUCTION SITE}

The Böhlen town gas production facility is located at an active olefin factory in Böhlen. The total area of the site is approximately $2.2 \mathrm{~km}^{2}$. The town gas is produced at the site through the combining of three gas mixtures: hydrogen gas $\left(\mathrm{H}_{2}\right)$, natural gas imported from Russia, and a low quality domestic natural gas (WESAG, 1992). They are combined according to quality standards of caloric worth. The imported natural gas contains $\sim 99 \% \mathrm{CH}_{4}$ and thus has a high caloric content. The domestic 
Table V. Böhlen town gas production

\begin{tabular}{lll}
\hline Type of gas & $\begin{array}{l}\text { Gas used (produced) } \\
1 / \min \end{array}$ & $\begin{array}{l}\mathrm{CH}_{4} \text { used (produced) } \\
1 / \mathrm{min}\end{array}$ \\
\hline Domestic natural gas & $4.19 \times 10^{5}$ & $1.34 \times 10^{5}$ \\
Imported natural gas & $4.85 \times 10^{5}$ & $4.80 \times 10^{5}$ \\
Town gas & $8.56 \times 10^{5}$ & $2.40 \times 10^{5}$ \\
\hline
\end{tabular}

gas is $\sim 32 \% \mathrm{CH}_{4}$ and $66 \% \mathrm{~N}_{2}$. The hydrogen gas is obtained from several sources at the olefin plant: the cracker, the benzine refinery and principally, from the steam reformer, which uses the Russian natural gas as a reactant.

The composition of the town gas is $28 \% \mathrm{CH}_{4}, 38 \% \mathrm{H}_{2}$ and $30 \% \mathrm{~N}_{2}$. The town gas is dried and odorized before it leaves the facility at a pressure of 20 bar. There are no compressors for the gas other than those used in the actual mixing process.

A modified tracer experiment was conducted at the Böhlen production facility on 20 May 1992. The wind was from the east at $1.1-1.2 \mathrm{~m} / \mathrm{s}$ at the start of the test, shifting to the north and increasing to $\sim 2 \mathrm{~m} / \mathrm{s}$ by the end of the test. There were limited roads downwind of the facility. Traverses were restricted to the road adjacent to the facility because of the lack of any other roads within several kilometers downwind of the site. On these traverses the methane mixing ratio in the facility's plume was approximately $10 \mathrm{ppm}$ above background. The estimated emission rate of the facility is $5240 \mathrm{l} / \mathrm{min}( \pm 40 \%)$.

The facility produces approximately $450 \times 10^{6} \mathrm{~m}^{3} / \mathrm{yr}\left(8.56 \times 10^{5} \mathrm{y} / \mathrm{min}\right)$ of town gas using approximately $220 \times 10^{6} \mathrm{~m}^{3} / \mathrm{yr}\left(4.19 \times 10^{5} \mathrm{l} / \mathrm{min}\right)$ of domestic natural gas and $255 \times 10^{6} \mathrm{~m}^{3} / \mathrm{yr}\left(4.85 \times 10^{5} \mathrm{~V} / \mathrm{min}\right)$ of imported natural gas (Sächsische Olefinwerke, 1993). In order to make comparisons with the measured $\mathrm{CH}_{4} \mathrm{emission}$ rate we have corrected for the methane content of each gas in Table $\mathrm{V}$. The emission rate of $\mathrm{CH}_{4}$ from the site is equal to $0.85 \%$ of the methane put into the town gas production.

\section{Conclusions}

Prior to our measurements in the former East Germany in May 1992 there was little known about the emissions from the region's gas systems. There was speculation that the emissions would be much higher than from corresponding sites in the United States. This was not the case for the limited number of sites we studied. We have reported here the results of studies of both anthropogenic and biogenic sources in the former East Germany, with the emphasis on methane emissions from gas system sources. Methane fluxes from pressure regulating stations in the urban distribution system ranged from 0.006 to $24 \mathrm{l} / \mathrm{min}$. Emissions from diffuse sources in urban areas were also measured with concentration maps and whole city flux experiments. The area fluxes of the two towns studied were 0.37 and $1.9 \mu \mathrm{g} / \mathrm{m}^{2} / \mathrm{s}$. Contrary to prior speculations, the emissions from the individual gas 
system stations and total town emissions of this study are comparable to those from similar sites examined in the United States. Suppositions about poor maintenance were determined to be unfounded in the towns and production site studied in this program. Eastern European gas systems did not appear to be as significant a methane source as previously believed. If the sites studied well represent other German and eastern European facilities, only to be determined from additional measurements, the atmospheric community may have to reexamine its understanding of the global methane budget. A decrease in the contribution of East Europe to the global methane source will need to be compensated by the identification of new sources, the greater contribution of already identified sources, or the re-examination and decrease of the total methane sink in the budget.

\section{Acknowledgements}

We acknowledge Dr Kathleen Hogan and the Global Change Division of the Office of Air and Radiation, U.S. EPA for providing both intellectual support and funding for the construction of the methane instrument and for the measurement program, and the Max Planck Institut für Chemie and the Institute for Tropospheric Research in Leipzig for providing laboratory facilities and support. The measurements would not have been possible without the cooperation of WESAG and the Sächsische Olefinwerke.

\section{References}

Bekki, S., Law, K. S. and Pyle, J. A., 1994: Effect of ozone depletion on atmospheric $\mathrm{CH}_{4}$ and $\mathrm{CO}$ concentrations, Nature 371, 595-597.

Benner, R. and Lamb, B., 1985: A fast response continuous analyzer for halogenated atmospheric tracers, J. Atmos. Ocean. Technol. 2, 582.

Blake, D. R., Woo, V. H., Tyler, S. C., and Rowland, F. S., 1984: Methane concentrations and source strengths in urban locations, Geophys. Res. Letr. 11, 1211-1214.

Blake, D. R. and Rowland, F. S., 1988: Continuing worldwide increase in tropospheric methane 1978-1987, Science 239, 1129-1131.

Crutzen, P. J., 1991, Methane's sinks and sources, Nature 350, 380-381.

Czepiel, P. M., Mosher, B., Shorter, J. H., McManus, J. B., Kolb, C. E., Allwine, E., Lamb, B. K., and Harriss, R. C., 1996: Landfill methane emissions measured by static enclosure and atmospheric tracer methods, J. Geophys. Res., in press.

Dlugokencky, E. J., Masaire, K. A., Lang, P. M., Tans, P. P., Steele, L. P., and Nisbet, E. G., 1994: A dramatic decrease in the growth rate of atmospheric methane in the northern hemisphere during 1992, Geophys. Res. Lett. 21, 45-48.

Fan, S. M., Wofsy, S. C., Bakwin, P. S., Jacob, D. J., Anderson, S. M., Kebabian, P. L., McManus, J. B., Kolb, C. E., and Fitzjarrald, D. R., 1992: Micrometeorological measurements of $\mathrm{CH}_{4}$ and $\mathrm{CO}_{2}$ exchange between the atmosphere and subarctic tundra, J. Geophys. Res. 97, 16,627-16,643.

Harrision, M. R. and Cowgill, R. M., 1996: Tier 2 draft report: summary of methane emissions from the natural gas industry (final report), Radian Corporation, Austin, TX.

Hogan, K. B. and Harriss, R. C., 1994: Comment on 'A dramatic decrease in the growth rate of atmospheric methane in the northem hemisphere during 1992' by E. J. Dlugokencky et al., Geophys. Res. Lett. 21, 2445-2446.

Hogan, K. B., Hoffman, J. S., and Thompson, A. M., 1991: Methane on the greenhouse agenda, Nature 354, 181-182. 
IPCC, 1990, Climate Change - The IPCC Scientific Assessment, Intergovernmental Panel on Climate Change, Cambridge University Press, Cambridge, England.

Kerr, R. A., 1994: Methane increase put on pause, Science 263, 751.

Lamb, B., Westberg, H., and Allwine, E. 1986: Isoprene emission fluxes determined by atmospheric tracer technique, Atmos. Environ. $20,1$.

Lamb, B. K., McManus, J. B., Shorter, J. H., Kolb, C. E., Mosher, B., Harriss, R. C., Allwine, E, Blaha, D., Howard, T., Guenther, A., Lott, R. A., Siverson, R., Westberg, H., and Zimmerman, P., 1995: Development of atmospheric tracer methods to measure methane emissions from natural gas facilities and urban areas, Environ. Sci. Technol. 29, 1468-1479.

Lelieveld, J. and Crutzen, P. J., 1992: Indirect chemical effects on methane on climate warming, Nature 355, 339-342.

McManus, J. B., Kebabian, P. L., and Kolb, C. E., 1989: Atmospheric methane measurement instrument using a Zeeman-split He-Ne Laser, Appl. Opt. 28, 5016-5023.

McManus, J. B. and Kebabian, P. L., 1990, Narrow optical interference fringes for certain setup conditions in multipass absorption cells of the Herriot type, Appl. Opt. 29, 898.

McManus, J. B., Shorter, J. H., Kolb, C. E., Mosher, B., Blaha, D., Harriss, R. C., Lamb, B., Allwine, E., Westberg, H., Howard, T., Gibbs, M. J., Woodbury, J., and Ryan, K., 1993: Methane emissions from natural gas distribution systems (final report report No. ARI-RR-931), Aerodyne Research, Inc., Billerica, MA.

McManus, J. B., Shorter, J. H., Kolb, C. E., Lamb, B. K., Siverson, R., Allwine, E., Westberg, H. H., Mosher, B. W., Harriss, R. C., and Howard, T., 1994: Results of tracer measurements of methane emissions from natural gas system facilities, International Workshop on Environmental and Economic Impact of Natural Gas Losses, Prague, Czech Republic.

McManus, J. B., Kebabian, P. L., and Kolb, C. E., 1991a: Aerodyne research mobile infrared methane monitor, in Measurement of Atmospheric Gases, SPIE Proceedings 1433, 330-339.

Rowland, F. S., Harris, N. R. P., and Blake, D. R., 1990: Methane in cities, Nature 347, 432-433.

Rudolph, J., 1994: Anomalous methane, Nature 368, 19-20.

Sächsische Olefinwerke, 1993: Private communication.

Shorter, J. H., McManus, J. B., Kolb, C. E., Allwine, E. J., Siverson, R., Lamb, B. K., Mosher, B. W., Harriss, R. C., Howard, T., and Lott, R. A., 1996: The collection of leakage statistics in the natural gas system by tracer methods, Oil and Gas Journal, in preparation.

Simmonds, P., Lovelock, A., and Lovelock, J., 1976: Continuous and ultrasensitive apparatus for the measurement of air-borne tracer substances, J. Chromatogr. 126, 3 .

Wallis, M. K., 1990: Leaky answer to greenhouse gas? Nature 344, 25-26.

Wallis, M. K., 1991: Leaking gas in the greenhouse, Nature 354, 428.

WESAG, 1992: Westsächsische Energie Aktiengesellschaft, private communication. 